УДК 324(477)

https://doi.org/10.34142/24130060.2019.17.1.12

\title{
ПОЛІТИКО-ПРАВОВІ АСПЕКТИ ЗАКОНОДАВЧОГО ЗАБЕЗПЕЧЕННЯ ВИБОРЧОГО ПРОЦЕСУ В СУЧАСНІЙ УКРАЇНІ
}

\section{Г.М. Нечасва}

Харківський національний педагогічний університет імені Г.С. Сковороди

В даній статті розглядаються етапи становлення виборчого процесу на підставі законодавства України про вибори з часу проголошення незалежної Украӥни до теперішнього часу. Значна увага приділяється розкриттю поняття «виборчий проиес», оскільки від демократизму виборів значною мірою залежить демократизм і легітимність усієї системи органів публічної влади. Зазначено про необхідність формування й утвердження стійкої виборчої культури виборців та стабільності виборчого законодавства для забезпечення належної реалізачії виборчих прав громадян України.

Ключові слова: вибори, виборча система, виборчий прочес, виборче законодавство.

\section{ИСТОРИЧЕСКИЕ АСПЕКТЫ ЗАКОНОДАТЕЛЬНОГО ОБЕСПЕЧЕНИЯ ИЗБИРАТЕЛЬНОГО ПРОЦЕССА В СОВРЕМЕННОЙ УКРАИНЕ}

\begin{abstract}
А.Н. Нечаева
В данной статье рассматриваются этапы становления избирательного процесса на основании законодательства Украинь о выборах с момента провозглатения независимости Украинь до настоящего времени. Значительное внимание уделяется раскрытию понятия «избирательный прочесс», поскольку от демократизма выборов в значительной степени зависит демократизм и легитимность всей системы органов публичной власти. Отмечена необходимость формирования и утверждения устойчивой избирательной культуры граждан и стабильности избирательного законодательства для обеспечения надлежащей реализачии избирательных прав граждан Украины.
\end{abstract}

Ключевые слова: выборы, избирательная система, избирательный процесс, избирательное законодательство.

\section{HISTORICAL ASPECTS OF THE LEGISLATIVE SUPPORT OF THE ELECTORAL PROCESS IN MODERN UKRAINE}

\section{H. Nechaeva}

This article examines the stages of the electoral process based on the legislation of Ukraine on elections since the proclamation of independent Ukraine until now. Considerable attention is paid to the disclosure of the concept of "electoral process", since democracy and the legitimacy of the entire system of public authorities depend to the electoral democracy. On the basis of various points of view of scientists, scholars of lawyers it can be concluded that the electoral process as a legal category is an independent legal institution of constitutional law,

(C) Г.М. Нечаєва, 2019 
which should be understood as a set of constitutional and procedural norms governing the formation of representative bodies of the state and other elected bodies of state power and bodies of local self-government, election of state officials. The issue of the legislative support of the electoral process in Ukraine, the problem of the formation of a system of electoral legislation in Ukraine on the basis of which the electoral process takes place - elections of the President of Ukraine, people's deputies of Ukraine, deputies of local councils and village, town and city mayors. Adequate reflection of the will of the citizens on the formation of a system of government, the creation of conditions for free and deliberate expression of will require not only the legislative consolidation of the principles of free and fair elections, but also detailed legal regulation of procedures for conducting an election campaign, determination of the status of the subjects of the electoral process, their rights and obligations defining the results of elections, etc. The necessity of formation and establishment of a stable electoral culture of voters and the stability of electoral legislation for ensuring the proper realization of the electoral rights of Ukrainian citizens is indicated. However, the main problem is not so much in adopting laws that would comply with generally accepted democratic principles, but in ensuring compliance with these principles in practice, which does not always lie in the field of legislative regulation. In order to ensure legality in the process of organizing and holding elections, the functioning and interaction of all branches of state power, local self-government bodies and public associations must be agreed upon.

Keywords: elections, electoral system, electoral process, electoral law.

Постановка проблеми. Домінантою сучасних демократій $є$ пошук оптимальної моделі виборчої системи як ефективного інструментарію демократичного функціонування політичних систем з можливістю реалізації ключового принципу демократії - народного волевиявлення. Ліберальнодемократичний вектор, що закладено в основу сучасного українського державотворення, від 1991 року й до теперішнього часу, спрямовано на пошук ефективної моделі виборчої системи, яка спирається на культурноісторичний, нормативно-правовий та суспільно-політичний досвід сталих демократій. Адже, реальним індикатором вдалої реалізації «демократичного проекту» сучасної правової України є можливість реалізації народом своєї влади - шляхом затвердження відповідних рішень та формування органів державної влади.

Втім, українська політико-правова архітектура, враховуючи «світові демократичні тренди», повинна вибудовувати власну модель виборчої системи, з урахуванням історичного минулого та надскладних суспільнополітичних викликів XXI століття, зокрема, перманентного суспільного запиту на пошук кращої моделі формування й функціонування держави. Відтак, вирішення питань, пов’язаних 3 модернізацією і оптимізацією 
виборчого процесу, потребують фахової наукової експертизи та конкретних практичних рішень, оскільки досвід західних демократій раз у раз доводить від демократизму виборів значною мірою залежить демократизм i легітимність усієї системи органів публічної влади, ступінь реалізації основних прав і свобод громадян.

Аналіз актуальних досліджень. За умов загальної демократизації, що стала однією 3 визначальних тенденцій сучасного світу, електоральний процес набуває детермінуючої ваги серед інших політичних процесів, а відтак й перебуває у центрі соціально-гуманітарного дискурсу. Провідні світові та вітчизняні експерти досліджують природу, механізми, специфіку виборчого процесу, зокрема проблеми методології виборчого процесу, його впливу на політичну систему суспільства розглядаються в роботах «В. Бебика, Б. Гаєвського, М. Головатого, А. Мельвіля, М. Мельника, Г. Почепцова, В. Ребкала, Ю. Римаренка, С. Рябова, І. Шкурата та інших. Національні українські електоральні традиції досліджували і досліджують А. Арциховський, А. Бєлоновські, М. Грушевський, В. Ключевський, М. Костомаров, В. Погорілко, Л. Тихомиров, Б. Чичерін та інші. Аналіз складових факторів та механізмів, що забезпечують перемогу у виборчій кампанії тим чи іншим політичним суб'єктам, знаходимо у працях К. Гаджієва, С. Кара-Мурзи, А. Ковлера, А. Лукашова, А. Максимова, Е. Малкіна, Д. Ольшанського, Е. Сучкова, А. Цуладзе та інших. Виборчий процес як механізм реалізації демократії в контексті теоретичних концептів демократії розглядається в працях Д. Аптера, Р. Даля, Г. Екстайна, А. Лейпхарта, Р. Мертона, А. Пшеворського, Й. Шумпетера та інших» (Поліщук, 2005, с. 140).

На складність дослідження виборчого процесу вказують й численні теоретико-методологічні інтерпретації, так, на думку авторитетного вітчизняного дослідника В. Погорілко (2010, с. 157), «виборчий процес це система врегульованих Конституцією та законами України основних послідовних процесуальних стадій організації та проведення виборів в 
Україні». Науковець В. Кравченко (2000, с. 120) зазначає, що «виборчий процес - це врегульована правовими та іншими соціальними нормами діяльність органів, організацій, окремих громадян, їх колективів і груп 3 підготовки та проведення виборів до представницьких та інших виборних органів державної влади і місцевого самоврядування». Провідний експерт 3 історії та сучасного виборчого права М. Ставнійчук (1999), під виборчим процесом розуміє: «врегульовану законом специфічну діяльність уповноважених органів і громадян держави, спрямовану на формування конституційного якісного і кількісного складу органів державної влади та органів місцевого самоврядування».

У суспільно-політичних міркуваннях В. Яворського (2000, с. 84-86), «зміст виборчого процесу включає складну структуру технологій як ефективного засобу забезпечення і захисту активного і пасивного виборчого права громадян України шляхом послідовного впровадження комплексу виборчих дій та процедур». Консолідована думка представників Центральної виборчої комісії України втілена у власному визначенні виборчого процесу, під яким розуміють урегульовану законами діяльність уповноважених органів та громадян держави, спрямовану на підготовку і проведення виборів представницьких органів державної влади та органів місцевого самоврядування, обрання та наділення повноваженнями посадових осіб.

Мета статті - дослідити генезис та охарактеризувати політико-правові аспекти законодавчого забезпечення виборчого процесу в сучасній Україні.

Виклад основного матеріалу. Ключовим імперативом сучасних демократій $\epsilon$ проведення вільних, чесних i справедливих виборів, які виступають запобіжником «консервації влади правлячою елітою, гарантують можливість безкровної зміни влади та створюють стимули, щоб уряд гнучко реагував на запити суспільства» (Поппер, 1992), а відтак, надається реальний шанс різним суспільно-політичним групам отримати владу. Саме тому, пріоритетним кроком у переформатуванні сучасної української політичної системи відповідно до ліберально-демократичних стандартів стає пошук 
оптимальної моделі виборчої системи, зокрема, врегулювання політикоправових аспектів законодавчого забезпечення виборчого процесу.

«Вихідним пунктом аналізу еволюції виборчого законодавства в незалежній Україні є вибори до Верховної Ради України, що відбулися у березні 1994 р., які проходили за новим Законом, прийнятим на восьмій сесії ВРУ ХІІ скликання 18 листопада 1993 р. Цей Закон, відповідав міжнародним стандартам проведення демократичних виборів» (Рибачук та Шкурат, 2004, c. 87).

«У зв’язку з прийняттям у червні 1996 р. Конституції України, настав якісно новий етап реформування виборчої системи. Конституція визначила як фундаментальний принцип організації державної влади вільні вибори, а носієм суверенітету і єдиним джерелом влади в Україні - народ як політичну спільність» (Рибачук та Шкурат, 2004, с. 90-91) Таким чином, у Конституції вперше знайшов своє відображення політичний i правовий статус громадянина України як суб’єкта виборчого процесу, а виборча політика i право отримали необхідні для їх збалансованого розвитку і гармонійного існування передумови.

«Вибори до ВРУ, що відбулися у березні 1998 р., проводилися за новим Законом «Про вибори народних депутатів України». Народні депутати обиралися громадянами України на основі загального, рівного і прямого виборчого права шляхом таємного голосування за змішаною системою. Це був крок вперед на шляху формування багатопартійної системи у нашій країні» (Киян та Окладна, 2013, с. 13). Наступний етап реформування виборчого законодавства розпочався з прийняття 5 березня 1999 р. Закону України «Про вибори Президента України». Він прямо закріплював добровільність участі громадян у виборах, відмовлявся від інституту призупинення активного виборчого права (для осіб, що перебувають у місцях позбавлення волі) і обмежував право голосу тільки для осіб, визнаних судом недієздатними. Надано право самовисування громадян як претендентів на 
зборах виборців, нормативно встановлено рівні права претендентів «незалежно від суб’ єкта висування».

Означені трансформаційні процеси призвели до суттєвих змін у політико-правових аспектах виборчої системи сучасної України, втім це був лише початок надскладного шляху з оптимізації законодавчого забезпечення виборчого процесу, відповідно до стандартів сучасних ліберальних демократій. Так, з 18 січня по 18 жовтня 2001 р., в результаті «гострих парламентських баталій» та 3 п’ятої спроби, ВРУ приймає Закон «Про вибори народних депутатів України», а Президент чотири рази накладав на нього вето і тільки останній варіант був підписаний. Основні принципові моменти, навколо яких точилася політична боротьба, - це вид виборчої системи, за якою повинні проводитися вибори до парламенту, тривалість виборчої кампанії, порядок формування виборчих комісій. Так, згідно 3 новим Законом України «Про вибори народних депутатів України», залишилась змішана мажоритарно-пропорційна виборча система. До принципових новел Закону можна віднести внесення грошової застави замість збирання підписів на підтримку політичної партії чи кандидата у депутати (Горленко, 2013).

Державна незалежність України відкрила перед українським народом можливість повноцінного ліберально-демократичного розвитку, а оскільки «ліберальна демократія спирається на верховенство закону і загальну рівність перед ним» (Головко, 2015), в експертних колах було продовжено масштабну роботу щодо оптимізації законодавчого забезпечення виборчого процесу. На сьогодні вибори в Україні регулюються такими найважливішими законодавчими актами, як: Конституція України; «Закон України «Про вибори Президента України» (зі змінами від 23.12.2015); Закон України «Про вибори народних депутатів України» (зі змінами від 16.02.2016); Закон України «Про Центральну виборчу комісію» (від 22.11.2018); Закон України «Про політичні партії в Україні» (зміни від 21.12.2017); Закон України «Про місцеві вибори» (зміни від 03.07.2018); Закон України «Про доступ до 
публічної інформації» (зміни від 09.04.2915)» (Центральна виборча комісія, 1998-2019); «Карний Кодекс України; Цивільно-процесуальний та Адміністративний Кодекси України; Укази Президента; рішення судів та Центральної виборчої комісії України. Світовою спільнотою у міжнародноправових актах вироблена низка норм, міжнародних виборчих стандартів у галузі прав людини, спрямованих на забезпечення вільних, справедливих виборів. Ці стандарти закріплені, зокрема, у Загальній декларації прав людини (Стаття 21), Міжнародному пакті про громадянські та політичні права (Стаття 25), Документі Копенгагенської наради Конференції 3 людського виміру НБСС (пункти 6 та 7), і визнають головним правом особи брати участь в управлінні країною, право обирати і бути обраним, право на рівний доступ до державної служби» (Малкин та Сучков, 2002, с. 130-133).

Разом 3 тим акцентуємо, «апгрейд» (модернізація) українського виборчого законодавчого окрім очевидних переваг має й певні проблемні моменти: «Аналіз розвитку виборчого законодавства дає підстави стверджувати, що існує тенденція до деталізації та розширення обсягу норм, які регламентують порядок здійснення виборчих процедур» (Чемсак, 2016, с. 228). «Часті зміни виборчого законодавства не сприяють формуванню й утвердженню стійкої виборчої культури громадян. Стабільність виборчого законодавства «має вкрай важливе значення для зміцнення авторитетності виборчого процесу»» (Ключковський ред., 2009, с. 73). «Кодекс належної практики у виборчих справах, прийнятий Венеціанською комісією у 2002 році, проголошує: «Основні елементи виборчого закону, зокрема, власне виборчу систему, склад виборчих комісій і визначення меж виборчих округів, не можна переглядати менш як за рік до проведення виборів», якщо вони не закріплені в конституції чи законі вищого рівня» (Ключковський ред., 2009, c. 57). «Порушення принципу стабільності виборчого законодавства знаходить свій вияв не лише у тому, що практично для кожних виборів приймається нова редакція закону. Не менш негативні наслідки для практики належного застосування виборчого законодавства мають зміни, що 
приймаються напередодні, а часом і під час виборчого процесу. На жаль, така практика досить поширена. Тому вимога стабільності виборчого законодавства передбачає також відмову від внесення законодавчих змін у період, коли внаслідок браку часу належне вивчення нових нормативних положень як суб’єктами виборчого процесу, так і організаторами виборів ускладнене. Такі ситуації не лише перешкоджають правильному й однаковому застосуванню законодавства про вибори під час виборчого процесу, але й порушують принцип правової визначеності - одну із складових принципу верховенства права» (Козюбра, 2013, с. 164).

«Вибори $\epsilon$ центральним елементом політичного процесу i визначальною характеристикою участі громадян у політичному житті демократичних країн» (Чоловська, 2017, с. 54). Комплексна робота щодо організації та проведення виборів в Україні здійснюється Центральною виборчою комісією (ЦВК). Згідно зі ст.1 Закону України «Про Центральну виборчу комісію», ЦВК є постійним діючим державним органом, який відповідно до Конституції та законів України забезпечує організацію підготовки та проведення виборів Президента України і народних депутатів України. Комісія здійснює контроль за діяльністю та консультативнометодичне забезпечення виборчих комісій, які утворюються для організації і підготовки виборів Президента України, народних депутатів України, депутатів місцевих рад і сільських, селищних, міських голів та комісій 3 місцевих референдумів (Філоненко, 2014, с. 25).

У сучасному світі вибори і виборчі процедури займають ключову роль у ефективному функціонуванні політичної системи - за допомогою виборів волевиявлення громадян перетворюється на державну владу. Вибори сполучна ланка між суспільством і державою. Для громадян парламент є не тільки органом державної влади, а й установою представництва їх інтересів (Майер, 2005, с. 18-19). Вибори - це розтягнутий у часі процес, і сам виборчий акт є лише незначною його частиною. Як юридичний інститут вибори припускають такі етапи, як призначення виборів, утворення виборчих 
органів, утворення виборчих округів та виборчих дільниць, складання списків виборців (реєстрація виборців), висування і реєстрація кандидатів, передвиборна агітація, голосування, підрахунок голосів виборців, встановлення та оприлюднення результатів виборів. Щодо кожного з цих етапів можуть бути прийняті законодавчі рішення, вигідні або невигідні для окремих партій та їх прихильників. Проте визначальну роль у правовій регламентації цих процедур відіграють політичні партії, представлені в парламенті, оскільки відповідні рішення, як правило, трансформуються у форму закону (Райковский, 2008, с. 56). Так, 7 листопада 2017 року Верховна Рада України прийняла в першому читанні Проект Виборчого кодексу України № 3112-1 від 2 жовтня 2015 року, в якому йдеться про регулювання загальних засад виборів, органи адміністрування виборчих процесів, реєстрацію та списки виборців, фінансове, матеріально-технічне та інформаційне забезпечення виборів, передвиборну агітацію, підготовку і проведення голосування та підрахунок голосів виборців та оскарження порушень виборчого законодавства (Центр політико-правових реформ, 19962019).

Означені політико-правові аспекти оптимізації виборчого процесу та модернізації виборчого законодавчого надають оптимізму щодо ліберальнодемократичної майбутнього України, проте на даний час, «постійно триває процес інтенсивного напрацювання нових за змістом та формою законодавчих актів, пошуку нових виборчих процедур, які, з одного боку, створюють або мають на меті створити можливості для гарантування виборчих прав громадян України, з іншого - забезпечують або спрямовані на забезпечення контролю за законністю виборів, унеможливлення фальсифікацій. Таким чином, в цілому виборче законодавство розвивається системно, комплексно, поступово набуваючи максимальної уніфікації виборчих процедур» (Середа ред., 2005-2017).

Висновки i перспективи подальших досліджень. Надскладний процес українського державотворення, що включає модернізацією виборчого 
законодавства та оптимізацією виборчого процесу відповідно до цінніснонормативних горизонтів сучасних ліберальних демократій - хронологічно розпочатий у 1991, складається $з$ декількох фундаментальних етапів (1993, 1996, 1998, 1999, 2001, 2015) та є незавершеним. Виборчий процес охоплює всю багатоманітність суспільно-політичних відносин, що виникають у зв’язку з формуванням органів державної влади, місцевого самоврядування та обранням посадових осіб. Він має свою внутрішню цілісність та відокремленість і розгортається у вигляді послідовно-регламентованих, спрямованих на забезпечення прийняття акту виборів, стадій. Від того, наскільки якісно організований виборчий процес у державі, залежить результат виборів, а отже, i належна реалізація виборчих прав громадян України. Саме тому, дослідження виборчого процесу та порядку проведення виборів потребує від сучасних науковців поглибленої теоретичної рефлексії та розробки практичного інструментарію, які сприятимуть модернізації політичної системи сучасної України.

\section{ЛІТЕРАТУРА}

1. Головко, I.В., 2015. Базові детермінанти формування ліберально-демократичних процесів у трансформаційних суспільствах. Сучасне суспільство: політичні науки, соиіологічні науки, культурологічні науки: збірник наукових праџь. 2(8), 1, с.13-26.

2. Горленко, В.В., 2013. Філософсько-правовий аналіз та історичні передумови становлення виборчої системи України. Вісник Наџіональної юридичної академії України. Політологія, [online] 2, с. 175-187 Доступно: http://nbuv.gov.ua/jpdf/Vnyua_2013_2_23.pdf [Дата звернення 25 січень 2019 ].

3. Ключковський, Ю. ред., 2009. Європейський демократичний доробок у галузі виборчого права: Матеріали Венечіанської Комісії, Парламентської Асамблеї, Комітету Міністрів, Конгресу місиевих і регіональних влад Ради Свропи. Київ: Логос.

4. Киян, М.Ш. та Окладна, М.Г., 2013. Деякі історичні аспекти формування виборчих технологій в українських землях. Громадянське суспільство, 69, с.8-13.

5. Козюбра, М., 2013. Верховенство права і Україна. Вісник Конституиіийної Асамблеї, 1, c. $146-178$.

6. Кравченко, В.В. 2000. Конституиійне право Украӥни. Київ: Атіка.

7. Майер, Х., 2005. Избирательное право как инструмент распределения власти. В: Н. И. Анисимова, О. М. Валуева, ред. Политические права и свободные выборы: Сборник докладов. Москва: Институт права и публичной политики. с.15-28.

8. Малкин, Е. та Сучков, Е. 2002. Основы избирательных технологий. Москва: Рус. панорама.

9. Погорілко, В.Ф. та Федоренко, В.Л. 2010. Конституиійине право України. Київ: Правова єдність. 
10. Поліщук, I.О., 2005. Виборчий процес як детермінанта сучасної політики. Політичний менеджмент: Украӥнський науковий журнал, 3, с.137-146.

11. Поппер, К., 1992. Открытое общество и его враги. Москва: Феникс, Международный фонд «Культурная инициатива».

12. Райковський, Б.С., 2008. Вибори як предмет політичного аналізу. Вісник Центральної виборчої комісії, 3(13), с. 56.

13. Рибачук, М. та Шкурат, М., 2004. Історичні аспекти становлення виборчої системи України. Політичний менеджмент, 1, с.83-98.

14. Середа, В.Я. ред., 2005-2017. Вісник Центральної виборчої комісії. [online] Доступно: http://www.cvk.gov.ua/visnyk/index.php?mID=10 [Дата звернення 3 лютий 2019]

15. Ставнійчук, М.І., 1999. Законодавство про вибори народних депутатів Украӥни: проблеми теорії $і$ практики. Кандидат наук. Автореферат. Київський університет імені Т.Г. Шоnline] Шевченка. Доступно: http://dysertaciya.org.ua/disertaciya_1_681.html [Дата звернення 2 лютий 2019 ].

16. Станкевич, Б., 2009. Політико-правові аспекти виборчих технологій та особливості їхнього використання в Україні. Украӥнська національна ідея: реалії та перспективи розвитку, 21, с. 162

17. Філоненко, О.А., 2004. Критерії здійснення обов'язкового пенсійного страхування. Наукові горизонти, 4, с. 25.

18. Центральна виборча комісія, 1998-2019. Нормативно-правова база. [online]. Доступно: http://www.cvk.gov.ua/metod/kultura/npa/ [Дата звернення 2 лютий 2019]

19. Центр політико-правових реформ, 1996-2019. Новини, напрямки діяльності. [online] Доступно: http://pravo.org.ua/ua/news/20872527-visnovok-schodo-proektu-viborchogokodeksu-ukrayini--3112-1-vid-2-geovtnya-2015-roku [Дата звернення 2 лютий 2019 ]

20. Чемсак, Ю.В., 2016. Основні тенденції та напрями правового регулювання виборчого процесу на сучасному етапі державотворення. Державне будівництво та місцеве самоврядування, 32, с. 228

21. Чоловська, О.П., 2017. Теоретико-методологічні особливості та компоненти порівняльного аналізу функціонування виборчих систем на місцевому рівні. Вісник Дніпропетровського університету, 2, с.54.

22. Яворський, В.Д., 2000. Сучасний виборчий процес в Україні: політико-правовий аспект. В: Вибори Президента України - 99: проблеми теорії $і$ практики: Зб. матеріалів міжнар. наук.-практ. конф. (доповіді, виступи, рекомендації) Київ: ЦВК.

\section{Інформація про автора}

Нечаєва Ганна Миколаївна - аспірантка кафедри політології, соціології і культурології Харківського національного педагогічного університету імені Г.С. Сковороди; e-mail pekines1@gmail.com; ORCID: http://orcid.org/0000-0002-3240-3555.

Стаття надійшла до редакції: 04.02.2019 р. $\quad$ Прийнята до друку: 18.02.2019 p. 